\title{
1909 BLERIOT MONOPLANE ADDED TO STATE MUSEUM
}

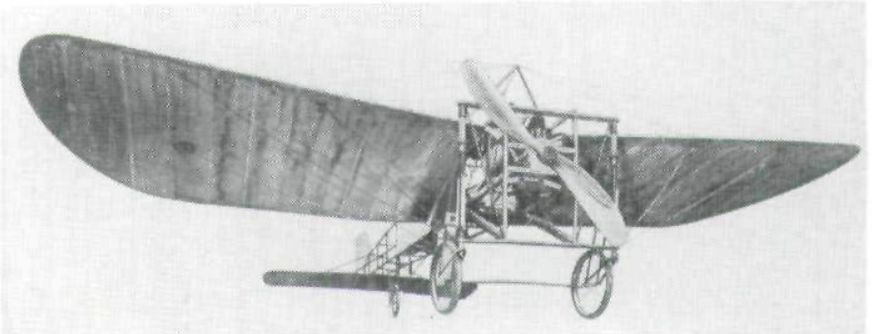

The 1909 Bleriot Monoplane, Bleriot XI, presented to the state of Iowa by E. D. (Hud) Weeks, is now on permanent display in the State Historical Building, East 12th and Grand, Des Moines. The monoplane was formally presented to the state of Iowa on April 14, 1967, at the Des Moines Flying Service; the airplane and its logbook were accepted by Jack W. Musgrove, Curator of the Iowa State Department of History and Archives.

Mr. Weeks, president of Weeks \& Leo Company, Inc., Des Moines, restored the Bleriot XI to flyable condition several years ago and the monoplane has been flown over Des Moines many times since. The plane flew at speeds from 35 to 80 miles per hour.

The Bleriot XI is believed to have been the once wrecked, stored, plane used by John B. Moisant flying circus-the group that performed the first airplane flying exhibition in Iowa at the Hyperion Club in Des Moines in 1911. This original model of one of the first successful monoplanes is now suspended in the rotunda of the Historical Building.

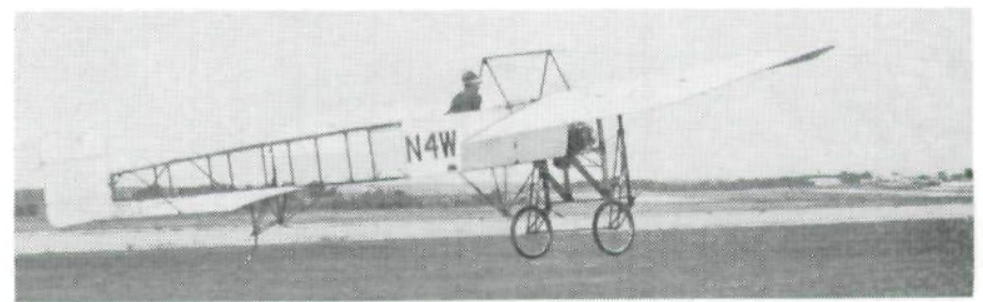

The Bleriot XI 
Copyright of Annals of Iowa is the property of State of Iowa, by \& through the State Historical Society of Iowa and its content may not be copied or emailed to multiple sites or posted to a listserv without the copyright holder's express written permission. However, users may print, download, or email articles for individual use. 